$\mathrm{AJ} H$

Received : 17.09.2014

Revised : 04.11.2014

Accepted : 18.11.2014

Author for correspondence : UDIT KUMAR

Department of Horticulture, Tirhut

College of Agriculture, Rajendra

Agricultural University, Dholi,

MUZAFFARPUR (BIHAR) INDIA

Email : udit_74@rediffmail.com
THE ASIAN JOURNAL OF HORTICULTURE

Volume 9 | Issue 2 | Dec., $2014 \mid$ |426-430

Visit us -www.researchjournal.co.in

RESEARCH PAPER

DOI : 10.15740/HAS/TAJH/9.2/426-430

\section{UDIT KUMAR}

ABSTRACT : Field experiment was conducted to compare various weed management practices in onion at Dholi farm, Tirhut College of Agriculture, RAU, Dholi, Muzaffarpur, Bihar. The study revealed that effective weed control was recorded under application of Oxyflurofen 23.5EC before planting + one hand weeding at 40 days after transplanting $\left(\mathrm{T}_{7}\right)$ or combined spray of Pendimethalin 30EC + quizalofop ethyl 5EC at the time of planting and second application at 30 days after transplanting $\left(\mathrm{T}_{6}\right)$. The same treatment $\left(\mathrm{T}_{7}\right)$ recorded significantly highest plant height $(58.33 \mathrm{~cm})$ and number of leaves (9.87) than rest of the treatments. Significantly highest marketable and total bulb yield was recorded in $\mathrm{T}_{7}$ (211.68and $242.33 \mathrm{q} / \mathrm{ha}$, respectively) followed by $\mathrm{T}_{6}(202.20$ and $232.62 \mathrm{q} / \mathrm{ha}$, respectively) than rest of the treatments. The result indicated that significantly highest weed population (1107.91 per sq $\mathrm{m}$ ) was recorded in weedy check plot $\left(\mathrm{T}_{8}\right)$ while lowest in $\mathrm{T}_{6}(195.42$ per sqm). The WCE varies from $41.01\left(\mathrm{~T}_{3}\right)$ to $68.23\left(\mathrm{~T}_{6}\right)$. The $\mathrm{BC}$ ratio estimated in different weed treatment practice over weedy check indicated maximum B:C ratio of 2.30 in $\mathrm{T}_{7}$ closely followed by 1.75 in $\mathrm{T}_{1}$ and 1.70 in $\mathrm{T}_{6}$.

KEY WORDS : Onion, Economics, Oxyflurofen, Pendimethalin, Quizalofop ethyl, WCE

HOW TO CITE THIS ARTICLE : Kumar, Udit (2014). Weed management studies in onion (Allium cepa L.). Asian J. Hort., 9(2) : 426-430. 